\title{
Patterns of Microglial Cell Activation in Frontotemporal Lobar Degeneration
}

Suzannah B Lant ${ }^{1}$, Andrew C Robinson ${ }^{1}$, Jennifer C Thompson ${ }^{1}$, Sara Rollinson ${ }^{2}$, Stuart Pickering-Brown², Julie S Snowden¹, Yvonne S Davidson¹, Alexander Gerhard ${ }^{1}$, David M A Mann ${ }^{1}$

Clinical and Cognitive Sciences Research Group, Institute of Brain, Behaviour and Mental Health, Faculty of Medical and Human Sciences, University of Manchester, ${ }^{1}$ Salford Royal Hospital, Salford, M6 8HD and 2A.V Hill Building, Oxford Rd, Manchester, M13 9PL, UK

Correspondence to:

Prof. David M.A. Mann,

Clinical and Cognitive Neuroscience Research Group,

University of Manchester,

Salford Royal Foundation NHS Trust,

Salford M6 8HD, UK.

Email: david.mann@manchester.ac.uk

Tel. +44 (0) 161-206-2580

Fax. +44 (0) 161-206-0388

Disclosure: This manuscript is the peer-reviewed version of the article Lant SB, Robinson AC, Thompson JC, Rollinson S, Pickering-Brown S, Snowden JS, Davidson YS, Gerhard A, Mann DM. Patterns of Microglial Cell Activation in Frontotemporal Lobar Degeneration. Neuropathol Appl Neurobiol. 2013 Oct 9. doi: 10.1111/nan.12092.

The final publication is available at http://onlinelibrary.wiley.com/doi/10.1111/nan.12092/abstract 


\section{Patterns of Microglial Cell Activation in Frontotemporal Lobar Degeneration}

Suzannah B Lant ${ }^{1}$, Andrew C Robinson ${ }^{1}$, Jennifer C Thompson ${ }^{1}$, Sara Rollinson ${ }^{2}$, Stuart Pickering-Brown ${ }^{2}$, Julie S Snowden ${ }^{1}$, Yvonne S Davidson ${ }^{1}$, Alexander Gerhard ${ }^{1}$, David M A Mann $^{1}$

Clinical and Cognitive Sciences Research Group, Institute of Brain, Behaviour and Mental Health, Faculty of Medical and Human Sciences, University of Manchester, ${ }^{1}$ Salford Royal Hospital, Salford, M6 8HD and ${ }^{2}$ A.V Hill Building, Oxford Rd, Manchester, M13 9PL, UK

Correspondence to:

Prof. David M.A. Mann,

Clinical and Cognitive Neuroscience Research Group,

University of Manchester,

Salford Royal Foundation NHS Trust,

Salford M6 8HD, UK.

Email: david.mann@manchester.ac.uk

Tel. +44 (0) 161-206-2580

Fax. $+44(0)$ 161-206-0388

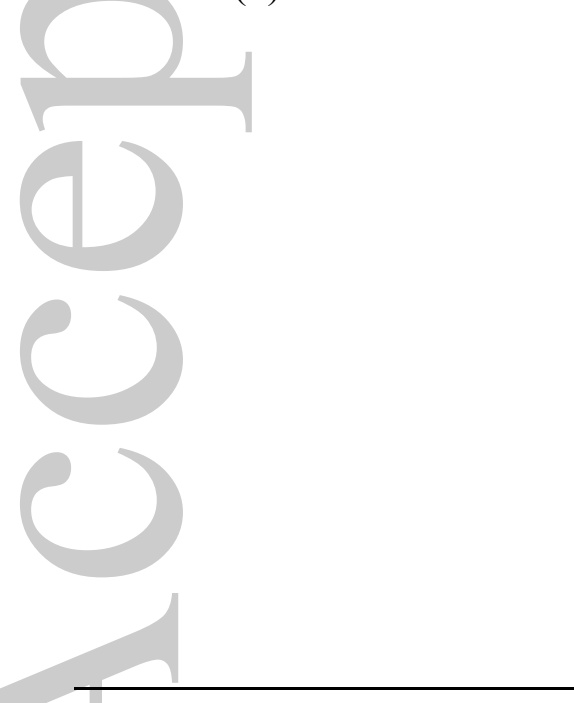

This article has been accepted for publication and undergone full peer review but has not been through the copyediting, typesetting, pagination and proofreading process, which may lead to differences between this version and the Version of Record. Please cite this article as doi: 10.1111/nan.12092 


\section{Abstract}

Aims: Pathological heterogeneity within patients with Frontotemporal lobar degeneration (FTLD) in general precludes the accurate assignment of diagnostic subtype in life. The aim of this study was to assess the extent of microglial cell activation in FTLD in order to determine whether it might be possible to employ this as a diagnostic marker in vivo using PET ligand $[11 \mathrm{C}](\mathrm{R})-\mathrm{PK} 11195$ in order to differentiate cases of FTLD according to histological subtype.

Methods: The distribution and extent of microglial cell activation was assessed semiquantitatively in cortical grey and subcortical white matter of CD68 immunostained sections of frontal and temporal cortex from 78 pathologically confirmed cases of FTLD, 13 of Alzheimer's disease (AD) and 13 controls.

Results: Significantly higher levels of microglial cell activation than controls occurred in all 4 regions in FTLD, and in 3 of the 4 regions in AD. Microglial activation was greater in frontal subcortical white matter in FTLD than AD, whereas it was higher in temporal cortical grey matter in AD than FTLD. Microglial cell activation was significantly higher in temporal subcortical white matter in FTLD-MAPT than in other genetic $(G R N, C 9 O R F 72)$ or nongenetic forms of FTLD.

Conclusions: The present study suggests that high levels of microglial cell involvement in temporal lobe (subcortical white matter) might serve as a marker of inherited FTLD associated with intronic mutations in $M A P T$, with a relatively intense signal in this region in PET studies using [11C](R)-PK11195 as microglial cell marker could indicate the presence of MAPT mutation in vivo.

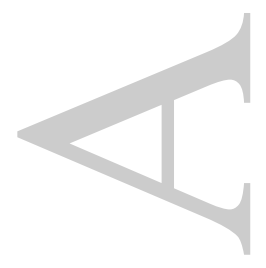




\section{Introduction}

After Alzheimer's disease (AD), Frontotemporal Lobar Degeneration (FTLD) is the second most common cause of dementia in the under $65 \mathrm{~s}$, accounting for $20 \%$ of cases [1]. It is a primary neurodegenerative disorder characterized by circumscribed neurodegeneration of the frontal and anterior temporal lobes. FTLD is clinically, pathologically and genetically, heterogeneous, and may in fact represent several distinct disorders united under this umbrella $[1]$.

In pathological terms, about half of cases can be defined by the presence of tauimmunoreactive changes in neurones, and sometimes glial cells, of the frontal and temporal cortex, and hippocampus, characterised by either neurofibrillary tangle-like structures or Pick bodies [2,3]; such cases have been designated as FTLD-tau [4], and some are associated with mutations in the tau gene, MAPT [5]. Most of the remaining cases of FTLD are associated with varying combinations of inclusion bodies (neuronal cytoplasmic inclusions (NCI), dystrophic neurites (DN) and neuronal intranuclear inclusions (NII) within neurones of the same regions of cerebral cortex and hippocampus [2,3]. These structures contain the transactive response (TAR) DNA binding protein with Mw 43kDa, TDP-43, [6,7], and such cases are termed FTLD-TDP [4]. Within the FTLD-TDP classification, four histological subtypes are recognised, and termed Types A to D according to the relative proportions of NCI, DN and NII [4]. About half of FTLD-TDP cases are associated with mutations in various genes, but chiefly as insertions/deletions in progranulin gene $(G R N)[8,9]$, and most recently in $C 9 O R F 72$ gene [10-12], where an expansion of a hexanucleotide repeat within the first intron has now been identified as responsible for disease [10,11]. Lastly, around 5\% of cases are characterized by NCI containing fused in sarcoma protein (FUS) [13], and are termed FTLD-FUS [4]. 
While to some extent there are some close clinical and pathological correlations (eg Semantic dementia (SD) and FTLD-TDP, type C, behavioural variant FTD (bvFTD) and Motor Neurone Disease (FTD+MND) and FTLD-TDP, type B) (see Neary et al [1]), for the most part, and especially so with respect to patients with bvFTD) it is not possible to predict the underlying histology from clinical presentation alone. Genetic analysis can help as mutations in GRN and C9ORF72 predict FTLD-TDP histology [4,9-12], with additional p62 immunoreactive changes within the cerebellum and hippocampus being characteristic of cases with C9ORF72 expansions [14-16]. MAPT mutations are always associated with an underlying tauopathy [5], though this can adopt differing histological appearances, either Pick body-like [17] or neurofibrillary tangle-like [18].

In order to develop rational therapeutic strategies for FTLD that seek to address or correct the underlying histological changes, it will obviously be necessary to be able to predict whether a case is FTLD-tau, FTLD-TDP or FTLD-FUS. As mentioned above, consistent clinicopathological correlations in SD and FTD+MND [1,19] would direct a TDP-43 based therapy, as would genetic changes in $G R N$ and $C 9 O R F 72$ [8-12]. However, such a rationale would not be applicable for most cases of bvFTD where an underlying tau, TDP-43 or FUS histology is possible [4], and if no identifiable gene is present, such cases could not be confidently differentiated on clinical assessment alone. A blood or cerebrospinal fluid based biomarker might be useful, though currently no such validated marker is available. PET imaging has been used to identify early cases of AD based on PIB binding to beta-amyloid plaques [20], and although PET markers that might have the potential to indicate the presence of tau pathology are currently being evaluated [21], there are no known equivalent pathologybased radioligands that could definitely identify the presence of, TDP-43 or FUS histology.

Over the last 10 years, it has become possible, using the PET ligand [11C](R)-PK11195, to image microglial activation, and this seems to correspond well to the distribution of the 
underlying pathological changes in Parkinson's disease and AD [22,23]. Small pilot studies have also been successful in showing the presence of microglial activation in vivo in progressive supranuclear palsy (PSP) and cortical basal degeneration (CBD) [24,25], and also in a small cohort of FTLD patients [26]. However, no correlative genetic or neuropathological data was available for any of these studies.

Given its heterogeneous pathology, it is possible that the different types of FTLD (ie FTLDtau, FTLD-TDP and FTLD-FUS) might show different patterns of microglial cell activation depending on the underlying pathology. Should this be the case a modality like $[11 \mathrm{C}](\mathrm{R})-$ PK11195 PET could clearly be helpful in differentiating FTLD subtypes in vivo. With this in mind, we sought to investigate patterns of microglial cell activation across the different clinical, histological and genetic forms of the disorder in an attempt to ascertain whether any one histological form of FTLD, especially those associated with bvFTD, might be differentiated according to the extent of this pathological change.

\section{Patients and Methods}

\section{Patients}

One hundred and four cases were investigated. All were obtained from the Manchester Brain Bank through appropriate consenting procedures for the collection and use of the human brain tissues. The patient groups comprised 78 patients with FTLD, 13 with AD and 13 control subjects (see on-line supplementary Table 1). The mean age of disease onset in the FTLD group was 60.0 \pm 8.6 years (range 43-73 years), the mean duration of disease was 7.6 \pm 3.7 years (range 2-18 years) and the mean age at death was $67.7 \pm 8.1$ years (range 45-77 years). The mean age of disease onset in the AD group was $64.4 \pm 12.2$ years (range 48-79 years), the mean duration of disease was $10.0 \pm 3.7$ years (range 5-18 years) and the mean age 
at death was $74.9 \pm 11.2$ years (range $57-87$ years). In the control group, mean age at death was $52.9 \pm 20.9$ years (range $26-87$ years).

All FTLD cases fulfilled the original Lund-Manchester clinical diagnostic criteria for FTLD $[27,28]$, and were consistent with recent consensus criteria $[29,30]$. All had been longitudinally assessed within the Cerebral Function Unit, Salford Royal Hospital, employing the Manchester Neuropsychological Test Battery. Data collected on each patient included gender, age at diagnosis and at death, and clinical diagnosis. All cases were from the Manchester Brain Bank. Pathological diagnoses were made by an experienced Neuropathologist (Professor David Mann) and genetic analyses (for C9ORF72, MAPT and $P G R N$ ) were performed in the laboratory of Professor Stuart Pickering-Brown (see $[5,8,11]$ for methodological details).

The FTLD group was composed of 46 males and 32 females (see on-line Supplementatry Table 1). Forty three patients had been clinically diagnosed with bvFTD, 9 with FTD+MND, 7 with SD, 8 with progressive non-fluent aphasia (PNFA), 9 with PSP/CBD, 1 with Multiple System Atrophy (MSA) and 1 with MND. According to the pathological classification of Mackenzie et al [4], 44 patients had FTLD-TDP, of which 19 had type A pathology, 18 had type B pathology and 7 had type C pathology. Thirty four cases had FTLD-tau, of which 8 had the histology of Pick's disease, 10 had tau pathology consistent with possession of exon 10 +16 MAPT mutation and 16 had CBD/PSP pathology.

Twenty seven of the FTLD cases bore a mutation on the MAPT, GRN or C9ORF72 gene. Of these, 8 bore a mutation on GRN gene, 1 with exon 1 C31LfsX34, 1 with exon 4 Q130SfsX124, 4 with exon 10 V452WfsX38 mutation, 1 with exon 10 Q468X, and 1 with exon 11 R493X. These all had FTLD-TDP type A pathology, 4 with bvFTD and 2 with PNFA. 10 patients bore $M A P T$ mutation ( 9 with +16 splice site mutation on intron to exon 10 
and 1 with +13 splice site mutation on intron to exon 10). The other 9 patients bore a hexanucleotide repeat expansion on C9ORF72 gene. Four of these had FTLD-TDP type A based pathology, with a diagnosis of bvFTD, and 5 had a pathological diagnosis of FTLDTDP type B, 3 with FTD+MND and 2 with bvFTD. The mean duration of disease for each mutation type was similar (8-10 years), though the mean age at onset of disease varied significantly $(60.5 \pm 5.1$ years for $G R N ; 51.6 \pm 5.7$ years for $M A P T$ and $59.6 \pm 6.3$ years for C9ORF72; $\mathrm{p}=0.028$ between $G R N$ and MAPT).

The 13 controls (6 males and 7 females) were judged to be clinically normal and none showed any pathology beyond that which might be anticipated for age. Three cases (over 65 years of age) showed mild deposition of amyloid beta protein, mostly in the form of diffuse amyloid plaques, one of which showed a mild neurofibrillary pathology confined essentially to the amygdala and hippocampal formation. Two other cases showed moderate cerebrovascular disease: the remaining 8 cases were apparently histologically normal. The 13 patients with $\mathrm{AD}$ all met pathological criteria for definite $\mathrm{AD}$ [31,32], and were Braak stage V or VI.

\section{Methods}

Immunohistochemistry

Sections of frontal (Brodmann areas 8/9) and temporal cortex (Brodmann areas 21/22) were cut at $6 \mu \mathrm{m}$ thickness from formalin fixed, paraffin embedded blocks and mounted on to glass slides. Sections were firstly hydrated through successive baths of xylene, alcohols of decreasing concentration and distilled water. Antigen unmasking was performed by pressure cooking in citrate buffer ( $\mathrm{pH} 610 \mathrm{mM})$ for 30 minutes, reaching 120 degrees Celsius and >15 $\mathrm{kPa}$ pressure. Sections were incubated for 30 minutes at room temperature in $0.3 \%$ peroxide 
in methanol to quench endogenous peroxidise activity, and then for a further 30 minutes at room temperature in Vectastain Elite PK-6101 goat serum as blocking buffer. Sections were then incubated for one hour at room temperature in mouse monoclonal antibody CD68 (Dako Cytomation, Glostrup, Denmark, DK-2600) at a concentration of 1:100. The sections were incubated for 30 minutes in a biotinylated secondary antibody followed by 30 minutes in Avidin Biotin Complex (ABC) reagent (both Vectastain Elite PK-6101 Rabbit IgG), both at room temperature. Sites of immunoreactions were visualised by incubating in DAB $\left(3,3^{\prime}-\right.$ diaminobenzidine tetrahydrochloride) for 5 minutes, followed by light counterstaining with haematoxylin (Vector H-3401). Sections were dehydrated and mounted for analysis under the microscope.

\section{$\underline{\text { Microscopic analysis }}$}

The CD68 antibody immunostains microglial cells, both in a resting (r) and activated (a) condition (Figure 1). Sections of frontal and temporal cortex were assessed for the presence of immunostained microglial cells within both the cortical grey and subcortical white matter at x20 magnification.

The frequency and 'severity' (in terms of morphological types, with activated microglial cells being considered to be more 'severe than ramified microglial cells) of CD68-immunostained sections was assessed according to:

$0=$ no immunostained cells present.

$1=$ very few immunostained cells present, all as ramified microglia.

$2=\mathrm{a}$ moderate number of immunostained cells present, mostly ramified but some activated cells present.

3 = many, diffusely spread, immunostained cells present, all as activated microglia. 
4 = many large clusters of activated microglial cells present.

All assessments were made by a single observer (SBL), blinded to diagnosis. Sections were scored twice to increase objectivity, and any discrepancies reconciled by consultation with a second observer (DMAM). In addition a random set of 8 sections were scored on a weekly basis over the course of the study.

\section{$\underline{\text { Statistical Analysis }}$}

Rating data was entered into an excel spreadsheet and analysed using Statistical Package for Social Sciences (SPSS) software (version 17.0). A p-value of less than 0.05 was considered statistically significant. The data was subjected to testing for homogeneity, skewness and kurtosis. If any of these results were significant, the data was considered non-parametric and Kruskal-Wallis test was performed when 3 or more groups were analysed. If this detected any significant differences between the groups, post-hoc testing was performed to identify the groups between which significant differences existed. Mann-Whitney test was used to compare rating data between pairs of groups.

\section{Results}

\section{Histological appearances}

Both the phenotype and physiological function of microglial cells are highly plastic, relating to their level of activity. As such, microglial morphology depends upon the type and degree of pathology present, and on signalling from other cellular structures, such as surrounding neurons and astrocytes. A 'ramified' microglial cell phenotype, characterised morphologically by a thin cell body with long, branching processes (Figure $1-r$ ) is seen when no apparent tissue pathology is present. Following Toll-like receptor-mediated 
recognition of endogenous damage-associated molecular patterns (DAMPs) or non-self pathogen-associated molecular patterns (PAMPs), microglial cells condense from a quiescent state of surveillance into a macrophage-like phagocytic phenotype (Figure 1 - a). In general, the topographic distribution of activated microglial cells followed that of the principal pathological changes present within the frontal and temporal cortex (ie amyloid and tau pathology), whether this was in FTLD or AD, or in the control cases.

In FTLD-TDP type A and type C cases, generally, there were more activated microglial cells in the upper (I-III) cortical layers than in the lower (IV-VI) cortical layers, and more so in the subcortical white matter than in the cortical grey matter. However, in FTLD-TDP type B cases, there was a more uniform distribution of microglial cells across the laminae of the cortical grey matter, with comparable levels of activated microglial cells in cortical grey and subcortical white matter.

In FTLD-tau associated with Pick bodies, there was a fairly uniform distribution of microglial cells across all laminae of the cortical grey matter, but these were generally more frequent in cortical grey (Figure 2a), than subcortical white (Figure 2b), matter, especially in areas where Pick bodies were dense (Figure 2c). However, in FTLD-tau associated with MAPT mutation, there were many more microglial cells in subcortical white (Figure 2d), than cortical grey (Figure 2e), matter, in line with the greater density of tau pathology in oligodendroglial cells in subcortical white matter (Figure 2f). In PSP/CBD, clustered microglial cells appeared less frequent in cortical grey (Figure 3a) than subcortical white (Figure 3b) matter, despite a high density of both astrocytic plaques in cortical grey matter (Figure 3c) and coiled bodies in subcortical white matter (Figure 3d).

As previously reported [33], microglial cells were more common in cortical grey matter in AD compared to subcortical white matter, often clustered within and around amyloid plaques 
(not shown). In the control cases (Figure 1), activated microglial cells were largely absent, though a few were occasionally seen in respect to rare amyloid deposits. Ramified microglial cells were commonly seen in many of these cases.

\section{Semiquantitative analyses}

Scores for microglial cell 'severity' in cortical grey and subcortical white matter, of both frontal and temporal cortex, were compared separately across, and within, the different diagnostic groups.

Microglial cell scores were highly significantly different between FTLD (overall), AD and control groups for temporal cortical grey matter $\left(\mathrm{F}_{2,103}=22.7 ; \mathrm{p}<0.001\right)$ and frontal cortical white matter $\left(\mathrm{F}_{2,104}=17.9 ; \mathrm{p}<0.001\right)$, and marginally significant for temporal cortical white matter $\left(F_{2,103}=65.6 ; p=0.059\right)$ and frontal cortical grey matter $\left(F_{2,84}=6.4 ; p=0.042\right)$. Post hoc testing showed microglial scores were higher in FTLD than controls in all 4 regions (frontal cortical grey matter $(\mathrm{p}=0.022)$, temporal cortical grey matter $(\mathrm{p}=0.022)$, frontal cortical white matter $(\mathrm{p}=0.001)$ temporal cortical white matter $(\mathrm{p}=0.023))$. Microglial scores were significantly higher in AD than controls in both frontal $(p=0.019)$ and temporal $(p<0.001)$ cortical grey matter, and also marginally so in temporal subcortical white matter $(\mathrm{p}=0.039)$, but not in frontal subcortical white matter $(\mathrm{p}=0.880)$. Moreover, microglial scores were significantly higher in frontal subcortical white matter in FTLD than in AD ( $p=0.002)$, but were higher in temporal cortical grey matter in AD than in FTLD $(p<0.001)$. There were no significant differences in scores for AD and FTLD in either frontal cortical grey matter $(p=0.609)$ or in temporal subcortical white matter $(p=0.929)$.

The FTLD cases were stratified according to histological subtype (ie FTLD-tau, FTLD-TDP) and differences in microglial scores were sought between subgroups. Overall, there were no significant differences in microglial cell scores between FTLD-tau and FTLD-TDP (frontal 
cortical grey matter $(\mathrm{p}=0.996)$, temporal cortical grey matter $(\mathrm{p}=0.226)$, frontal subcortical white matter $(p=0.531)$ or temporal subcortical white matter $(p=0.287))$, though if the PSP/CBD cases were excluded, there was significantly higher microglial scores in both temporal cortical grey $(\mathrm{p}=0.022)$ and subcortical white $(\mathrm{p}=0.017)$ matter in FTLD-tau than FTLD-TDP $(\mathrm{p}=0.022)$.

Microglial cell scores differed significantly between FTLD-tau subtypes (Picks vs MAPT vs $\mathrm{CBD} / \mathrm{PSP})$ in temporal cortical grey $\left(\mathrm{F}_{2,34}=6.8 ; \mathrm{p}=0.034\right)$ and subcortical white $\left(\mathrm{F}_{2,34}=10.04\right.$; $\mathrm{p}=0.007)$ matter, but not in frontal cortical grey $\left(\mathrm{F}_{2,34}=0.84 ; \mathrm{p}=0.656\right)$ or subcortical white $\left(\mathrm{F}_{2,34}=2.4 ; \mathrm{p}=0.296\right)$ matter. Post hoc testing for temporal cortex showed that there were significantly higher microglial scores in FTLD-MAPT cases than CBD/PSP cases for both cortical grey $(\mathrm{p}=0.009)$ and subcortical white $(\mathrm{p}=0.001)$ matter, but there were no significant differences between FTLD-MAPT and FTLD-Picks ( $\mathrm{p}=0.237$ and $\mathrm{p}=0.101$, respectively), or FTLD-Picks and PSP/CBD ( $\mathrm{p}=0.490$ and $\mathrm{p}=0.320$, respectively) cases. On the other hand, there were no significant differences in microglial scores between any of the FTLD-TDP histological subtypes (ie type A vs type B vs type C) for any of the 4 regions (frontal cortical grey matter $\left(\mathrm{F}_{2,44}=2.7 ; \mathrm{p}=0.254\right.$, frontal cortical white matter $\left(\mathrm{F}_{2,44}=4.4 ; \mathrm{p}=0.111\right)$, temporal cortical grey matter $\left(\mathrm{F}_{2,43}=0.25 ; \mathrm{p}=0.882\right)$ temporal subcortical white matter $\left(\mathrm{F}_{2,43}=1.9\right.$; $\mathrm{p}=0.387))$

FTLD cases were also compared according to genetic subtype (ie GRN vs C9ORF72 vs $M A P T$ vs no known genetic association). Microglial cell scores again differed significantly between the genetic subtypes in temporal subcortical white matter $\left(F_{4,61}=10.0 ; p=0.040\right)$ and marginally so in temporal cortical grey matter $\left(\mathrm{F}_{4,61}=8.7 ; \mathrm{p}=0.069\right)$ matter, but not in frontal cortical grey $\left(\mathrm{F}_{4,62}=1.07 ; \mathrm{p}=0.898\right)$ or subcortical white $\left(\mathrm{F}_{4,62}=2.8 ; \mathrm{p}=0.598\right)$ matter. Post hoc testing showed that microglial scores were significantly higher in MAPT mutation cases than 
in $G R N(\mathrm{p}=0.003)$ or $C 9 O R F 72(\mathrm{p}=0.054)$ cases, or in cases with no gene association $(p=0.009)($ Figure 4).

In the control group, there were no significant correlations between microglial cell scores in either frontal or temporal cortical grey or subcortical white matter and age at death.

\section{Discussion}

In the present study we have assessed and compared levels of microglial cell activation in frontal and temporal cortical grey and subcortical white matter regions in cases of FTLD and AD versus control subjects, and within FTLD cases alone have compared differed histological and genetic subtypes. As would be expected, we found higher levels of microglial cell activation than controls in all 4 regions in FTLD, and in 3 of the 4 regions studied in AD. Microglial cell activation was greater in frontal subcortical white matter in FTLD compared to $\mathrm{AD}$, whereas it was higher in temporal cortical grey matter in $\mathrm{AD}$ compared to FTLD. Such observations emphasize the importance of neuroinflammation, both microglial and astrocytic in origin, in neurodegenerative disease [34-36].

The patterns of microglial cell activation in FTLD and AD are likely to reflect the distribution of other pathologies, with the well known association between microglial cells and amyloid plaques, especially cored plaques [33], leading to high cortical grey matter levels in AD compared to FTLD and controls, and the intense oligodendoglial tau pathology in subcortical white matter in FTLD cases associated with intronic mutations in exon 10 [18].

When comparing FTLD cases, although levels of microglial cell activation were higher 'across the board' than in controls, no significant differences were noted when comparing FTLD-tau with FTLD-TDP-43 groups, or when FTLD-TDP histological (type A vs type B vs type $C$ ) or genetic ( $G R N$ vs $C 9 O R F 72)$ subtypes were compared, suggesting that microglial 
activation is generally upregulated in both tau and TDP-related pathologies. A number of studies have also implied this [37,38].

Nonetheless, it was found that against this general increase in microglial cell activation across all major histological subtypes, the level of microglial cell activation in temporal subcortical white matter in FTLD-MAPT cases was significantly higher compared with that in the same region in CBD/PSP cases or in the other genetic forms of FTLD (ie GRN, C9ORF72 or no known mutation), though no differences across these groupings were seen in the other 3 brain regions This finding was perhaps unexpected since it is known that PGRN regulates brain inflammatory responses, and that there is upregulation of PGRN in microglial cells in patients bearing GRN mutations [39]. Consequently, it might have been anticipated that cases with GRN mutations and TDP type A histology would also have displayed relatively high levels of microglial cell activation compared to other genetic or histological subtypes. However, it has been recently shown that microgliosis only occurs in homozygous GRN knock-out mice, and although heterozygotes display a similar clinical phenotype, resembling human bvFTD, this is not associated with any inflammatory brain changes [40]. Hence, heterozygous GRN mutations in human FTLD, while directing PGRN haploinsufficiency, may not as shown here be associated with any (excessive) microglial cell activation, and that microgliosis here may derive indirectly from (products of) the neurodegenerative process involving neuronal cell death, rather than via a direct activation of microglial cells through PGRN deficiency.

Nonetheless, the present study suggests that high levels of microglial cell involvement in temporal lobe (subcortical white matter) might serve, at least, as a surrogate for that form of inherited FTLD associated with intronic mutations in MAPT. Such correlations between the amount or extent of microglial cell activation in the underlying pathology and genetic 
predisposition have potential implications for PET studies aimed at imaging microglial cell activation in vivo with $[11 \mathrm{C}](\mathrm{R})-\mathrm{PK} 11195$. In this context the relatively intense signal in the subcortical white matter of the temporal lobe (compared to other histological and genetic forms of FTLD) could indicate the presence of a MAPT mutation.

\section{Acknowledgement}

We acknowledge the support of Alzheimers Research UK and Alzheimer's Society through their funding of the Manchester Brain Bank under the Brains for Dementia Research (BDR) initiative. DMAM and SPB also receive funding from MRC and Wellcome Trust which supported this study in part. AG has received funding from EU FW7 large scale integrating project INMiND (www.uni-muenster.de/InMind)

Suzannah Lant did all the immunohistochemistry and microscopical assessments, and helped with paper writing

Andrew Robinson prepared sections for staining and immunohistochemistry Jennifer Thompson did data analysis

Julie Snowden helped with statistical advice and clinical data Yvonne Davidson provided technical support and training

Alexander Gerhard helped with discussions and paper writing

David Mann provided study design, supervision, helped with microscopical assessments and wrote the paper

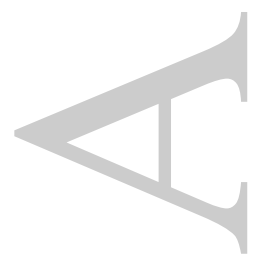




\section{References}

1. Neary D, Snowden JS, Mann DMA. Frontotemporal lobar degeneration: clinical and pathological relationships. Acta Neuropathol 2007; 114: 31-8

2. Shi J, Shaw CL, Richardson AMT, Bailey K, Tian J, Varma AR, Neary D, Snowden JS, Mann DMA. Histopathological changes underlying frontotemporal lobar degeneration with clinicopathological correlation. Acta Neuropathol 2005; 110: 50112

3. Baborie A, Griffiths TD, Jaros E, Richardson A, Ferrari R, Moreno J, Momeni P, McKeith IG, Burn DJ, Duplessis D, Pal P, Rollinson S, Pickering-Brown SM, Thompson JC, Neary D, Snowden JS, Perry R' Mann DMA. Pathological correlates of Frontotemporal Lobar Degeneration in the elderly. Acta Neuropathol 2011; 122: 36573

4. Mackenzie IRA, Neumann M, Baborie A, Sampathu DM, Du Plessis D, Jaros E, Perry RH, Trojanowski JQ, Mann DMA, Lee V M-Y. A harmonized classification system for FTLD-TDP pathology. Acta Neuropathol 2011; 122: 111-3

5. Hutton M, Lendon CL, Rizzu P, Baker M, Froelich S, Houlden M, Pickering-Brown SM, Chakraverty S, Isaacs A, Grover A, Hackett J, Adamson J, Lincoln S, Dickson D, Davies P, Petersen RC, Stevens M, de Graaf E, Wauters E, van Baren J, Hillebrand M, Joosse M, Kwon JM, Nowotny P, Che LK, Norton J, Morris JC, Reed LA, Trojanowski JQ, Basun H, Lannfelt L, Neystat M, Fahn S, Dark F, Tannenberg T, Dodd P, Hayward N, Kwok JBJ, Schofield PR, Andreadis A, Snowden J, Craufurd D, Neary D, Owen F, Oostra BA, Hardy J, Goate A, van Swieten J, Mann DM, Lynch T, Heutink P. Association of missense and 5'-splice-site mutation in tau with inherited dementia FTDP-17. Nature 1998; 393: 702-5

6. Arai T, Hasegawa M, Akiyama H, Ikeda K, Nonaka T, Mori H, Mann D, Tsuchiya K, Yoshida M, Hashizume Y, Oda T. TDP-43 is a component of ubiquitin-positive taunegative inclusions in frontotemporal lobar degeneration and amyotrophic lateral sclerosis. Biochem Biophys Res Commun 2006; 351: 602-11

7. Neumann M, Sampathu DM, Kwong LK, Truax AC, Micsenyi MC, Chou TT, Bruce J, Schuck T, Grossman M, Clark CM, McCluskey LF, Miller BL, Masliah E, Mackenzie IR, Feldman H, Feiden W, Kretzschmar H, Trojanowski JQ, Lee VM (2006) Ubiquitinated TDP-43 in frontotemporal lobar degeneration and amyotrophic lateral sclerosis. Science 2006; 314: 130-3

8. Baker M, Mackenzie IRA, Pickering-Brown SM, Gass J, Rademakers R, Lindholm C, Snowden J, Adamson J, Sadovnick AD, Rollinson S, Cannon A, Dwosh E, Neary D, Melquist S, Richardson A, Dickson D, Eriksen J, Robinson T, Zehr C, Dickey CA, Crook R, McGowan E, Mann D, Boeve B, Feldman H, Hutton M. Mutations in Progranulin cause tau-negative frontotemporal dementia linked to chromosome 17. Nature 2006; 442: 916-9 
9. Cruts M, Gijselinck I, van der Zee J, Engelborghs S, Wils H, Pirici D, Rademakers R, Vandenberghe R, Dermaut B, Martin JJ, van Duijn C, Peeters K, Sciot R, Santens P, De Pooter T, Mattheijssens M, Van den Broeck M, Cuijt I, Vennekens K, De Deyn PP, Kumar-Singh S, Van Broeckhoven C. Null mutations in progranulin cause ubiquitin-positive frontotemporal dementia linked to chromosome 17q21 Nature 2006; 442: 920-4

10. DeJesus-Hernandez M, Mackenzie IR, Boeve BF, Boxer AL, Baker M, Rutherford NJ, Nicholson AM, Finch NA, Flynn H, Adamson J, Kouri N, Wojtas A, Sengdy P, Hsiung GY, Karydas A, Seeley WW, Josephs KA, Coppola G, Geschwind DH, Wszolek ZK, Feldman H, Knopman DS, Petersen RC, Miller BL, Dickson DW, Boylan KB, Graff-Radford NR, Rademakers R. Expanded GGGGCC Hexanucleotide repeat in noncoding region of C9ORF72 causes chromosome 9p-linked FTD and ALS. Neuron 2011; 72: 245-56

11. Renton AE, Majounie E, Waite A, Simón-Sánchez J, Rollinson S, Gibbs JR, Laaksovirta H, Schymick JC, van Swieten J, Myllykangas L, Kalimo H, Paetau A, Abramzon Y, Remes AM, Kaganovich A, Scholz SW, Duckworth J, Ding J, Harmer DW, Hernandez DG, Johnson JO, Mok K, Ryten M, Trabzuni D, Guerreiro RJ, Orrell RW, Neal J, Murray A, Pearson J, Jansen IE, Sondervan D, Seelaar H, Blake D, Young K, Halliwell N, Callister J, Toulson G, Richardson A, Gerhard A, Snowden J, Mann D, Neary D, Nalls MA, Peuralinna T, Jansson L, Isoviita V-M, Kaivorinne AL, Holtta-Vuori M, Ikonen E, Sulkava R, Benatar M, Wuu J, Chio A, Restagno G, Borghero G, Sabatelli M, The ITALSGEN Consortium, Heckerman D, Rogaeva E, Zinman L, Rothstein J, Sendtner M, Drepper C, Eichler EE, Alkan C, Abdullaev Z, Pack SD, Dutra A, Pak E, Hardy J, Singleton A, Williams NM, Heutink P, PickeringBrown S, Morris HR, Tienari PJ, Traynor BJ. A hexanucleotide repeat expansion in C9ORF72 is the cause of chromosome 9p21-linked amyotrophic lateral sclerosisfrontotemporal dementia. Neuron 2011; 72: 257-68

12. Snowden JS, Rollinson S, Thompson JC, Harris J, Stopford CL, Richardson A, Jones M, Gerhard A, Davidson Y, Robinson A, Gibbons L, Hu Q, Halliwell N, DuPlessis D, Neary D, Mann DMA, Pickering-Brown S. Distinct clinical characteristics in patients with frontotemporal dementia and C9ORF72 mutations: a study of demographics, neurology, behaviour, cognition, and histopathology. Brain 2012; 135: 693-708

13. Neumann M, Rademakers R, Roeber S, Baker M, Kretzschmar HA, Mackenzie IR. A new subtype of frontotemporal lobar degeneration with FUS pathology. Brain 2009; 132: $2922-31$

14. Boxer AL, Mackenzie IR, Boeve BF, Baker M, Seeley WW, Crook R, Feldman H, Hsiung G-Y, Rutherford N, Laluz V, Whitwell J, Fote D, McDade E, Molano J, Karydas A, Wojtas A, Goldman J, Mirsky J, Sengdy P, DeArmond S, Miller BL, Rademakers R. Clinical, neuroimaging and neuropathological features of a new chromosome 9p-linked FTD-ALS family. J Neurol Neurosurg Psychiatry 2011; 82: 196-203 
15. Al-Sarraj S, King A, Troakes C, Smith B, Maekawa S, Bodi I, Rogelj B, Al-Chalabi A, Hortobagyi T, Shaw CE. p62 positive, TDP-43 negative, neuronal cytoplasmic and intranuclear inclusions in the cerebellum and hippocampus define the pathology of C9orf72-linked FTLD and MNA/ALS. Acta Neuropathol 2011; 122: 691-702

16. King A, Maekawa S, Bodi I, Troakes C, Al-Sarraj S. Ubiquitinated, p62 immunopositive cerebellar cortical neuronal inclusions are evident across the spectrum of TDP-43 proteinopathies but are only rarely additionally immunopositive for phosphorylation-dependent TDP-43. Neuropathology 2011; 31: 239-49

17. Pickering-Brown SM, Baker M, Yen S-H, Liu W-K, Hasegawa M, Cairns NJ, Lantos PL, Rossor M, Iwatsubo T, Davies Y, Allsop D, Furlong R, Owen F, Hardy J, Mann DMA, Hutton M. Pick's disease is associated with mutations in the tau gene. Ann Neurol 2000; 48: 859-67

18. Pickering-Brown SM, Richardson AMT, Snowden JS, McDonagh AM, Burns A, Braude W, Baker M, Liu W-K, Yen S-H, Hardy J, Hutton M, Davies Y, Allsop D, Craufurd D, Neary D, Mann DMA. Inherited frontotemporal dementia in 9 British families associated with intronic mutations in the tau gene. Brain 2002; 125: 732-51

19. Hodges JRD, Rhys R, Xuereb J, Casey H, Barney H, Broe M, Bak TH, Kril JJ, Halliday GM. Clinicopathological correlates in frontotemporal dementia. Ann Neurol 2004; 56: 399-406

20. Nordberg A, Carter SF, Rinne J, Drzezga A, Brooks DJ, Vandenberghe R, Perani D, Forsberg A, Langstrom B, Scheinin N, Karrasch M, Nagren K, Grimmer T, Miederer I, Edison P, Okello A, Van Laere K, Nelissen N, Vandenbulcke M, Garibotto V, Almkvist O, Kalbe E, Hinz R, Herholz K. A European multicentre PET study of fibrillar amyloid in Alzheimer's disease. Eur J Nucl Med Mol Imaging 2013; 40: 10414

21. Kepe V, Bordelon Y, Boxer A, Huang SC, Liu J, Thiede FC, Mazziotta JC, Mendez MF, Donoghue N, Small GW, Barrio JR. PET Imaging of Neuropathology in Tauopathies: Progressive Supranuclear Palsy. J Alzheimers Dis 2013; 36: 145-53

22. Gerhard A, Pavese N, Hotton G, Turkheimer F, Es M, Hammers A, Eggert K, Oertel $\mathrm{W}$, Banati RB, Brooks DJ. In vivo imaging of microglial activation with [(11)C](R)PK11195 PET in idiopathic Parkinson's disease. Neurobiol Dis 2006; 21: 404-12

23. Edison P, Archer HA, Gerhard A, Hinz R, Pavese N, Turkheimer FE, Hammers A, Tai YF, Fox N, Kennedy A, Rossor M, Brooks DJ. Microglia, amyloid, and cognition in Alzheimer's disease: An [11C](R)PK11195-PET and [11C]PIB-PET study. Neurobiol Dis 2008; 32: 412-9. 
24. Gerhard A, Trender-Gerhard J, Turkheimer I, Banati F, Quinn NP, Bhatia KP, Brooks DJ. In vivo imaging of microglial activation with [11C](R)-PK11195 PET in progressive supranuclear palsy. Mov Disord 2006; 21: 89-93

25. Gerhard AW, Trender-Gerhard J, Turkheimer I, Banati F, Bhatia KP, Brooks DJ. In vivo imaging of microglial activation with $[11 \mathrm{C}](\mathrm{R})-\mathrm{PK} 11195$ PET in corticobasal degeneration. Mov Disord 2004; 19: 1221-6

26. Cagnin A, Rossor M, Sampson EL, Mackinnon T, Banati RB. In vivo detection of microglial activation in frontotemporal dementia. Ann Neurol 2004; 56: 894-7

27. Brun A, Englund E, Gustafson L, Passant U, Mann DMA, Neary D, Snowden JS. Clinical, neuropsychological and neuropathological criteria of fronto-temporal dementia. J Neurol Neurosurg Psychiatry 1994; 57: 416-8

28. Neary D, Snowden JS, Gustafson L, Passant U, Stuss D, Black S, Freedman M, Kertesz A, Robert PH, Albert M, Boone K, Miller BL, Cummings J, Benson DF. Frontotemporal lobar degeneration: a consensus on clinical diagnostic criteria. Neurology 1988; 51: 1546-54

29. Rascovsky K, Hodges JR, Knopman D, Mendez MF, Kramer JH, Neuhaus J, van Swieten JC, Seelaar H, Dopper EG, Onyike CU, Hillis AE, Josephs KA, Boeve BF, Kertesz A, Seeley WW, Rankin KP, Johnson JK, Gorno-Tempini ML, Rosen H, Prioleau-Latham CE, Lee A, Kipps CM, Lillo P, Piguet O, Rohrer JD, Rossor MN, Warren JD, Fox NC, Galasko D, Salmon DP, Black SE, Mesulam M, Weintraub S, Dickerson BC, Diehl-Schmid J, Pasquier F, Deramecourt V, Lebert F, Pijnenburg Y, Chow TW, Manes F, Grafman J, Cappa SF, Freedman M, Grossman M, Miller BL. Sensitivity of revised diagnostic criteria for the behavioural variant of frontotemporal dementia. Brain 2011; 134: 2456-77

30. Harris JM, Gall C, Thompson JC, Richardson AMT, Neary D, du Plessis D, Pal, P, Mann DMA, Snowden JS, Jones M. Sensitivity and specificity of FTDC criteria for behavioral variant Frontotemporal dementia. Neurology 2013; 80: 1881-7

31. Mirra SS, Heyman A, McKeel D, Sumi SM, Crain BJ, Brownlee LM. The Consortium to Establish a Registry for Alzheimer's Disease (CERAD). Part II. Standardization of the neuropathologic assessment of Alzheimer's disease. Neurology 1991; 41: 479-86

32. Hyman BT, Phelps CH, Beach TG, Bigio EH, Cairns NJ, Carrillo MC, Dickson DW, Duyckaerts C, Frosch MP, Masliah E, Mirra SS, Nelson PT, Schneider JA, Thal DR, Thies B, Trojanowski JQ, Vinters HV, Montine TJ. National Institute on Aging Alzheimer's Association guidelines for the neuropathologic assessment of Alzheimer's disease. Alzheimers's and Dementia 2012; 8: 1-13 
33. Mann DMA, Younis N, Jones D, Stoddart RW. The time course of pathological events concerned with plaque formation in Down's syndrome with particular reference to the involvement of microglial cells. Neurodegeneration 1992; 1: 201-15

34. Cooper PN, Siddons CA, Mann DMA. Patterns of glial cell activity in frontotemporal dementia (lobar atrophy). Neuropathol Appl Neurobiol 1996; 22: 17-22

35. Schofield, E.K., C. Shepherd, C. E. Kril, J. J. Halliday, G. M. Severity of gliosis in Pick's disease and frontotemporal lobar degeneration: tau-positive glia differentiate these disorders. Brain 2003; 126: 827-40

36. Cagnin A, Kassiou M, Meikle SR, Banati RB. In vivo evidence for microglial activation in neurodegenerative dementia. Acta Neurol Scand Suppl 2006; 185:107-14

37. Bhaskar K, Konerth M, Kokiko-Cochran ON, Cardona A, Ransohoff RM, Lamb BT. Regulation of tau pathology by the microglial fractalkine receptor. Neuron 2010; 68: 19-31

38. Philips T, De Muynck L, Thu HN, Weynants B, Vanacker P, Dhondt J, Sleegers K, Schelhaas HJ, Verbeek M, Vandenberghe R, Sciot R, Van Broeckhoven C, Lambrechts D, Van Leuven F, Van Den Bosch L, Robberecht W, Van Damme P. Microglial upregulation of progranulin as a marker of motor neuron degeneration. $J$ Neuropathol Exp Neurol 2010; 69: 1191-1200

39. Ahmed ZM, Hutton M, Dickson D. Progranulin in frontotemporal lobar degeneration and neuroinflammation. Journal of Neuroinflammation 2007; 4: 7

40. Filiano AJ, Martens LH, Young AH, Warmus BA, Zhou P, Diaz-Ramirez G, Jiao J, Zhang Z, Huang EJ, Gao F-B, Farese RV, Roberson ED. Dissociation of Frontotemporal dementia-related deficits and neuroinflammation in progranulin haploinsufficient mice. Journal of Neuroscience 2013; 33: 5352-5361

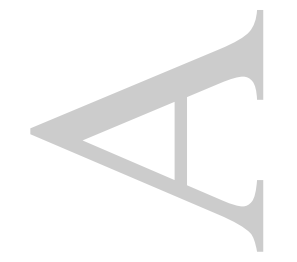




\section{Legends to Figures}

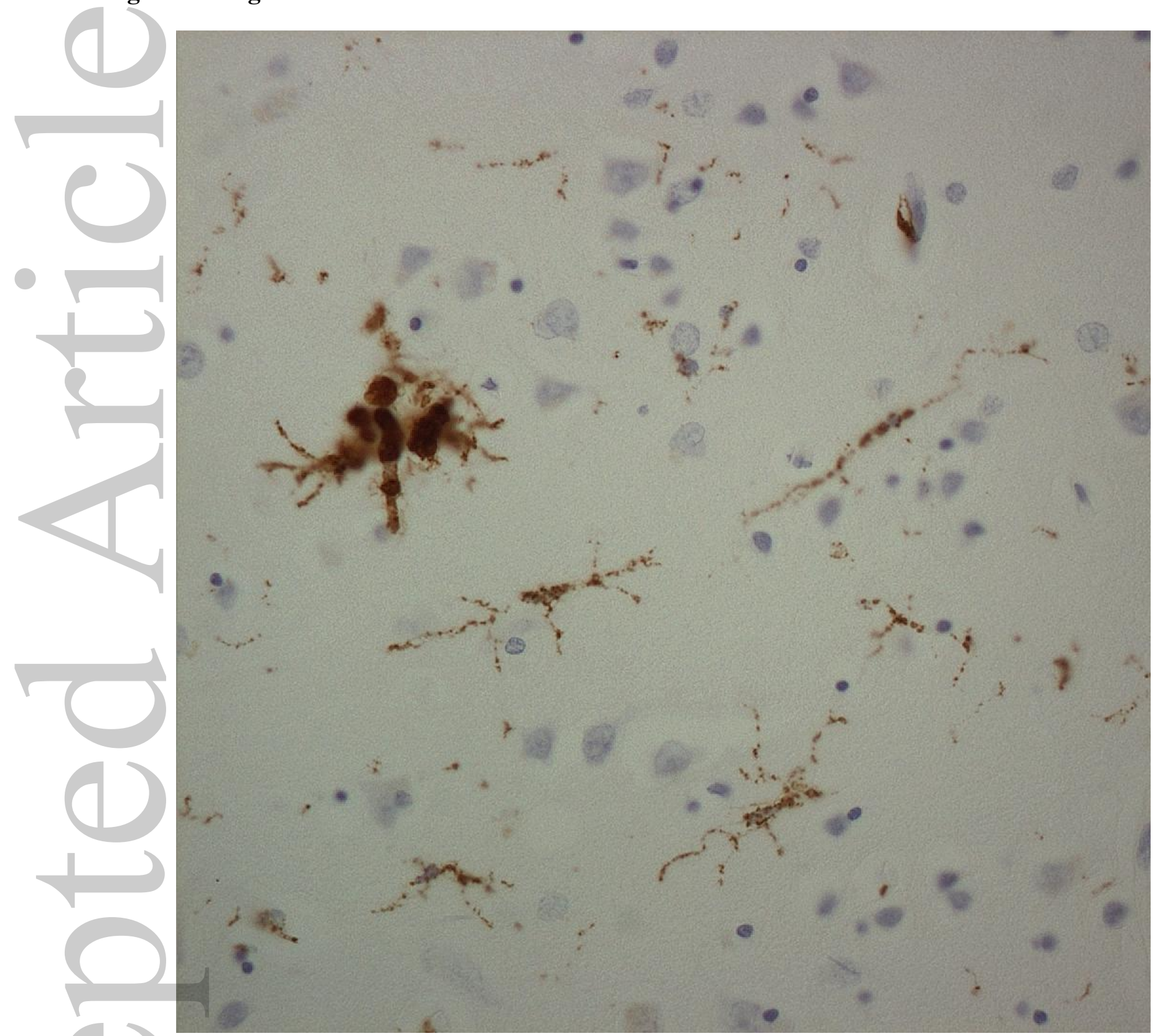

Figure 1. Activated (a) and ramified (r) microglial cells, as seen in CD68 immunostaining.

Immunoperoxidase - haematoxylin; x40 microscope objective magnification

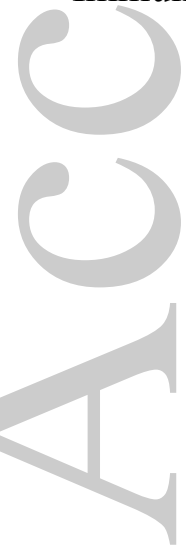




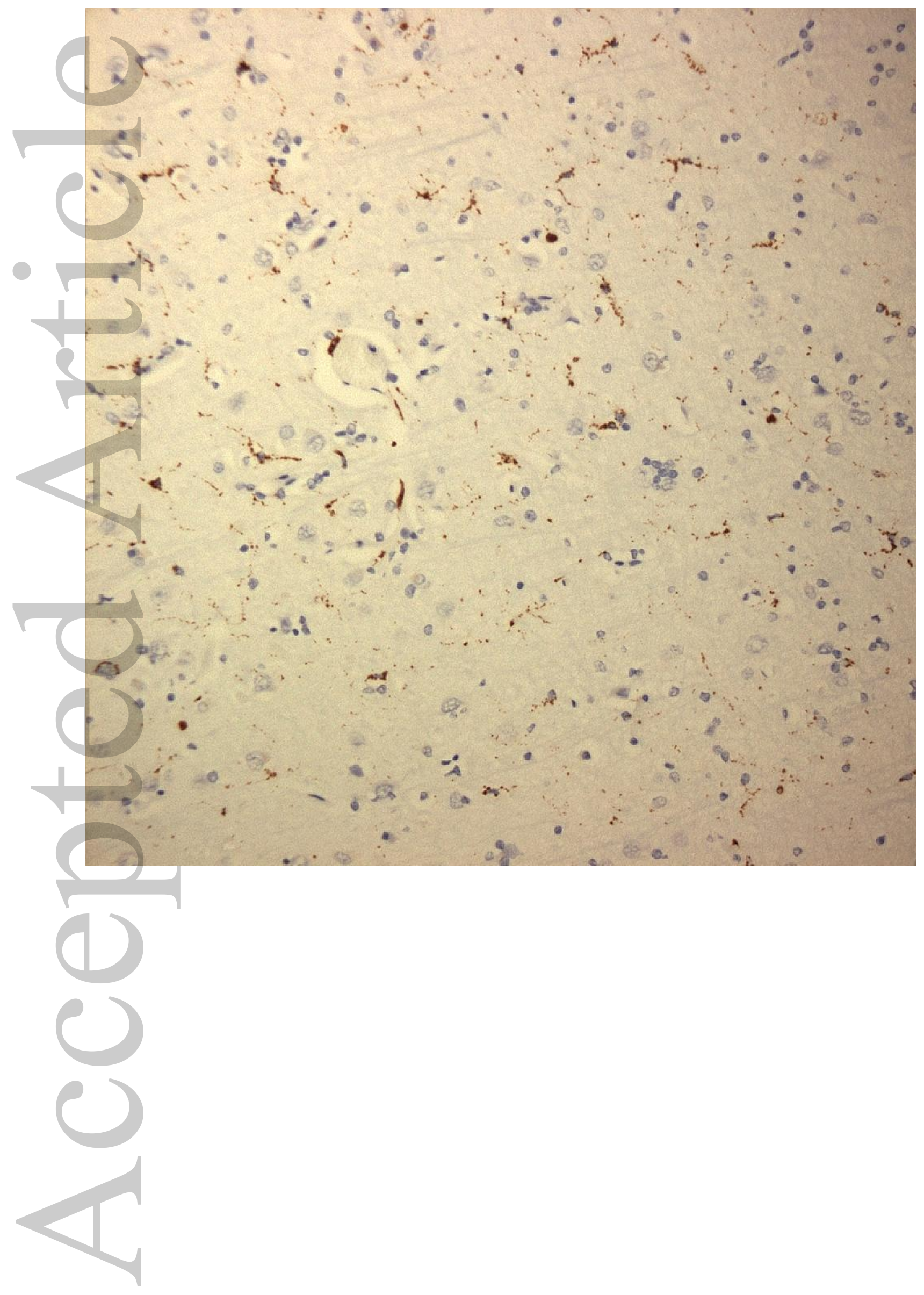



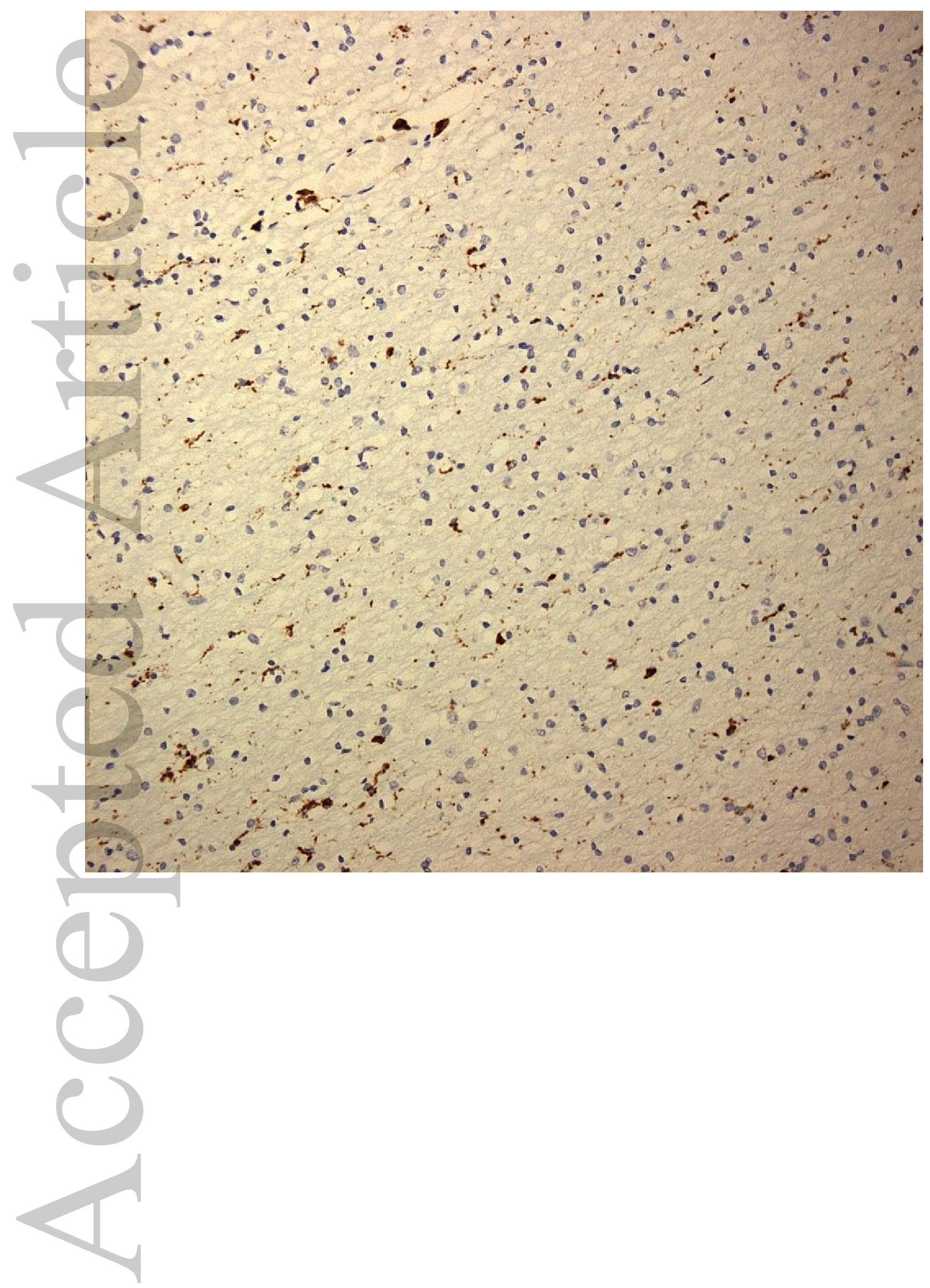

This article is protected by copyright. All rights reserved. 

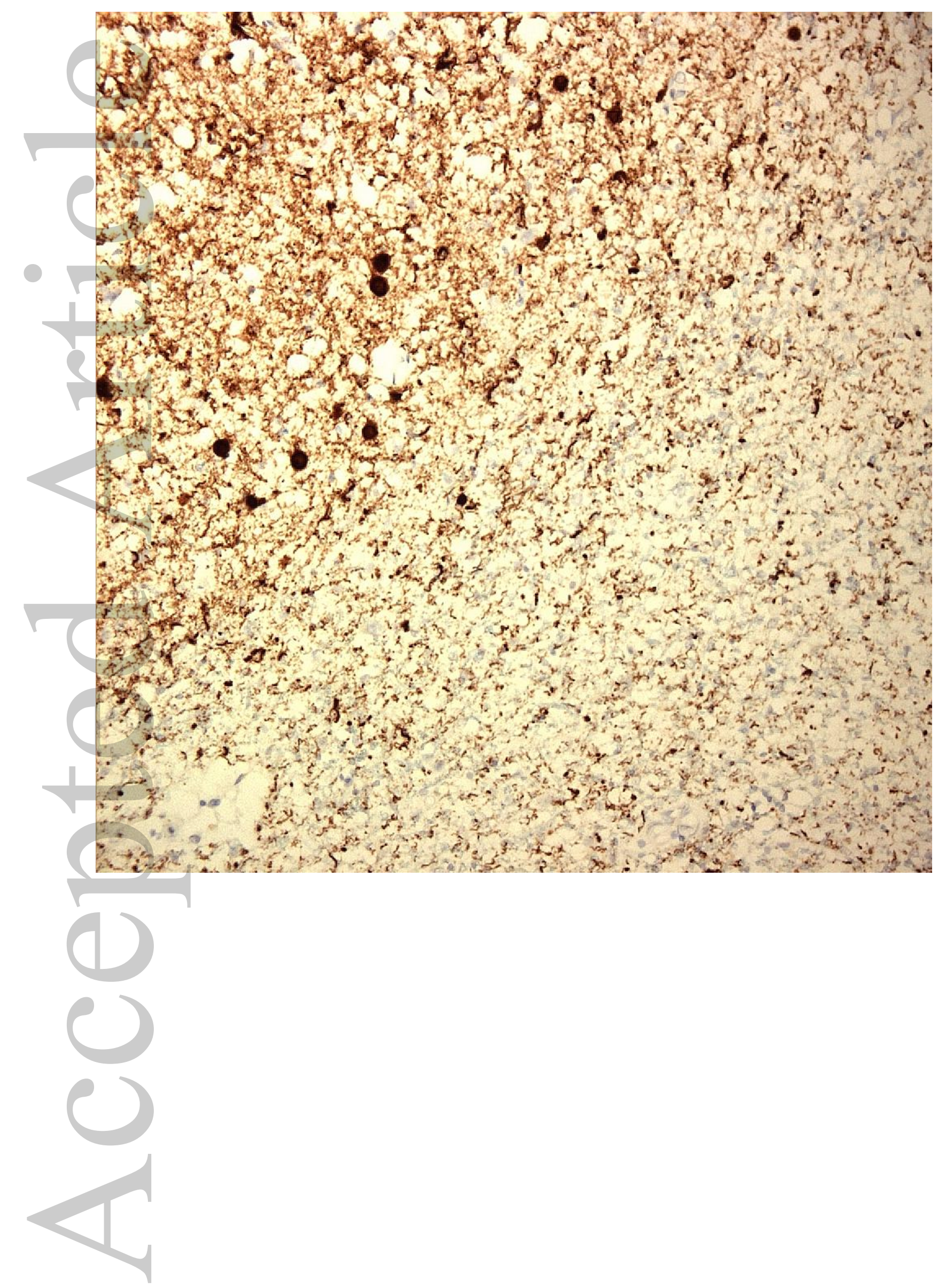

This article is protected by copyright. All rights reserved. 


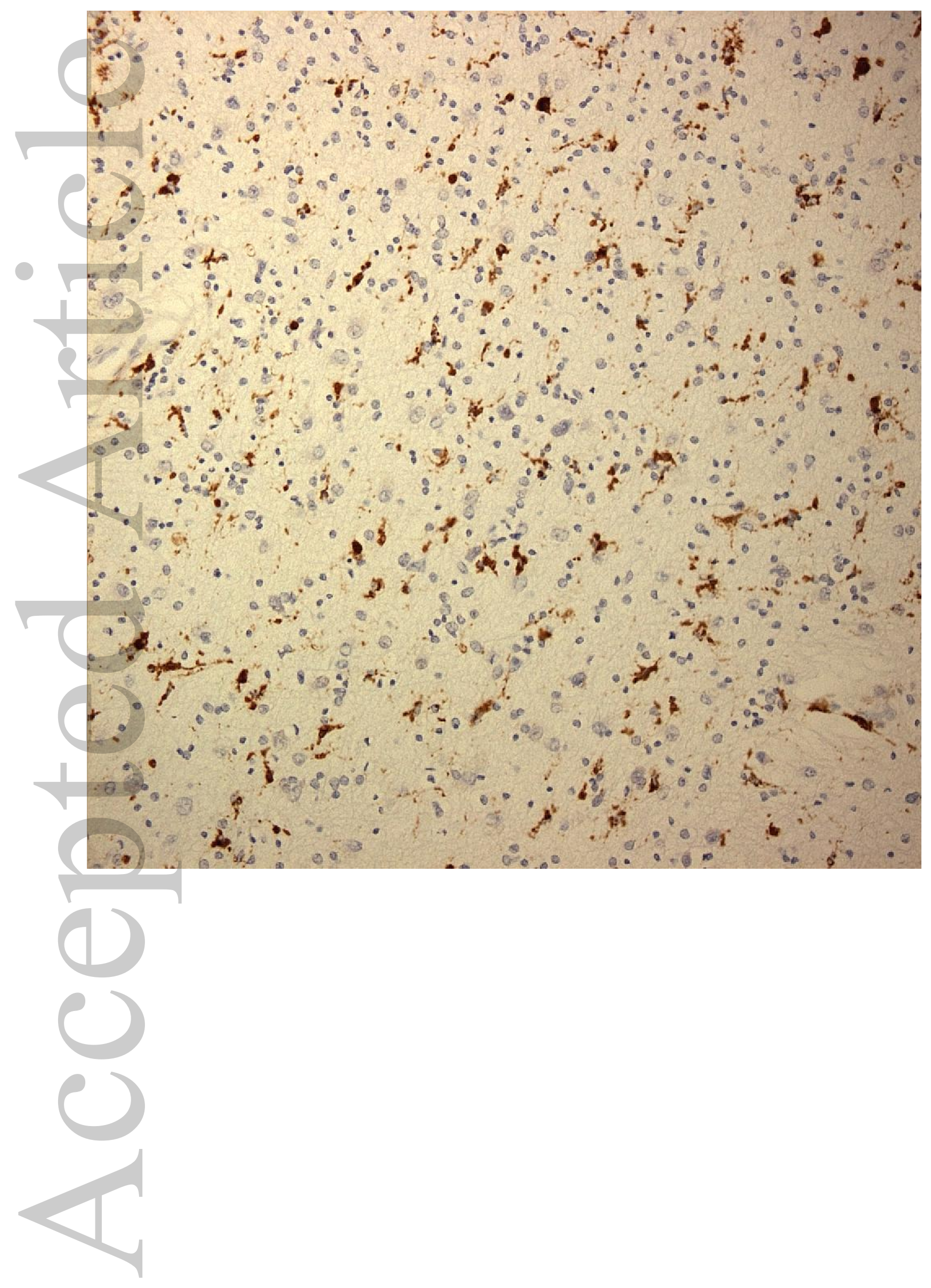

This article is protected by copyright. All rights reserved. 


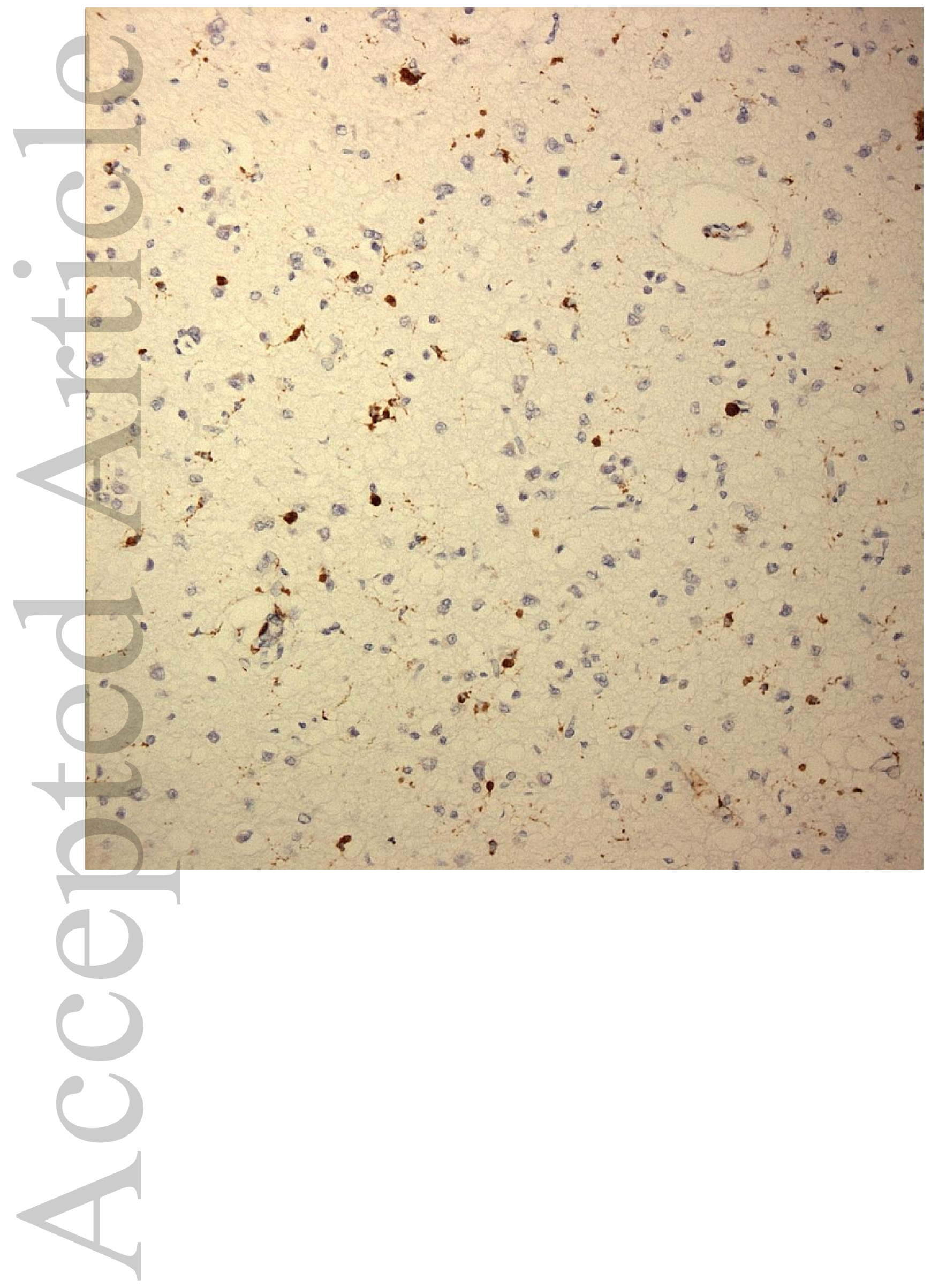




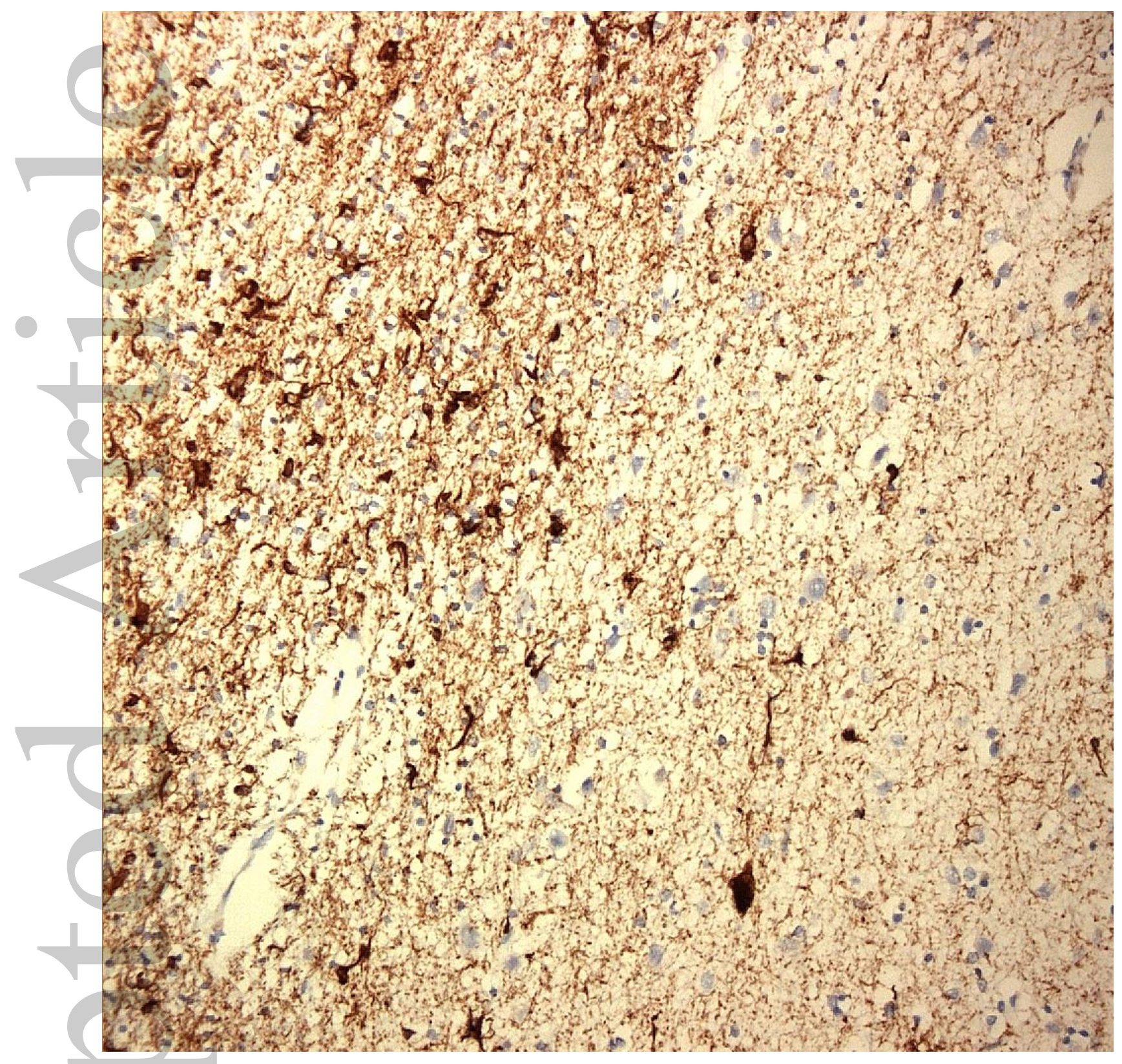

Figure 2. Microglial cells in grey (a) and white (b) matter in FTLD-tau with Pick bodies.

Microglial cells are often clustered in outer and deeper (a) cortical layers where Pick bodies

are most frequent (c). In FTLD-tau with exon $10+16$ MAPT mutation, microglial cells are

denser in white (d) than grey (e) matter, in line with greater involvement of oligodendroglial

cells in white matter by tauopathy, than of neurones and glia in grey matter (f).

CD68 immunoperoxidase (a,b,d,e), x40 microscope magnification.

AT8 (tau) immunostaining (c,f), x20 microscope magnification.

This article is protected by copyright. All rights reserved. 


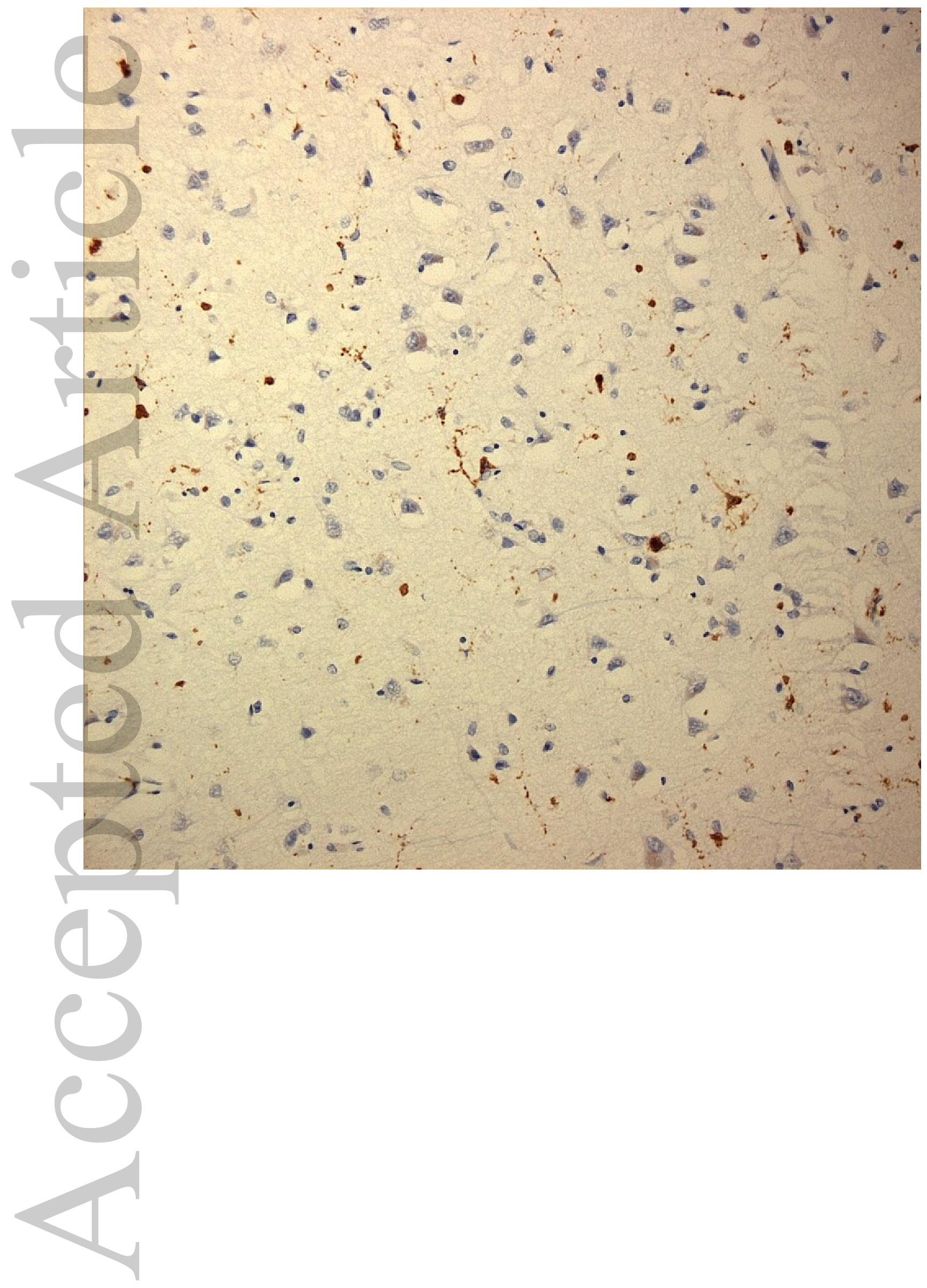



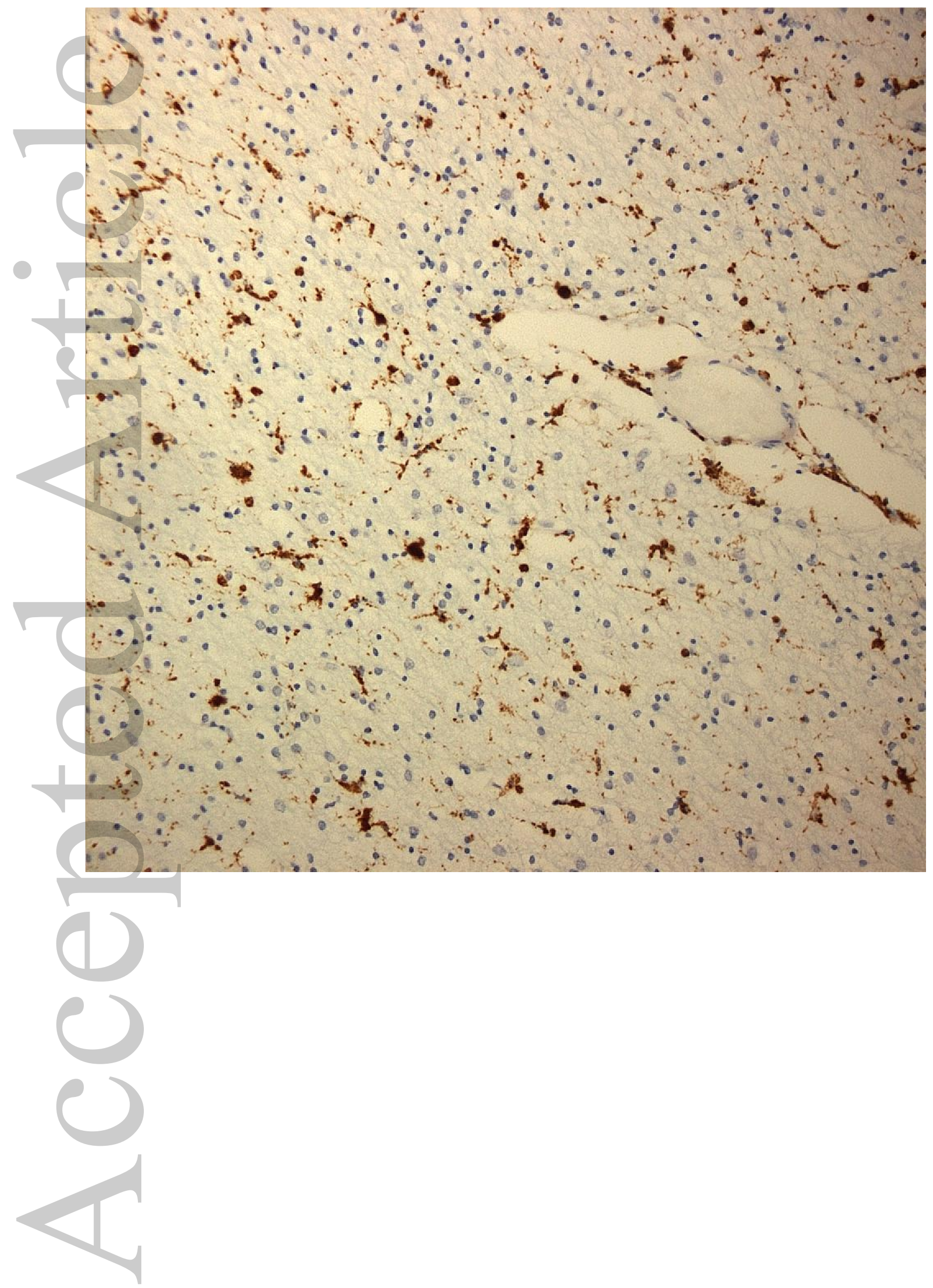

This article is protected by copyright. All rights reserved. 

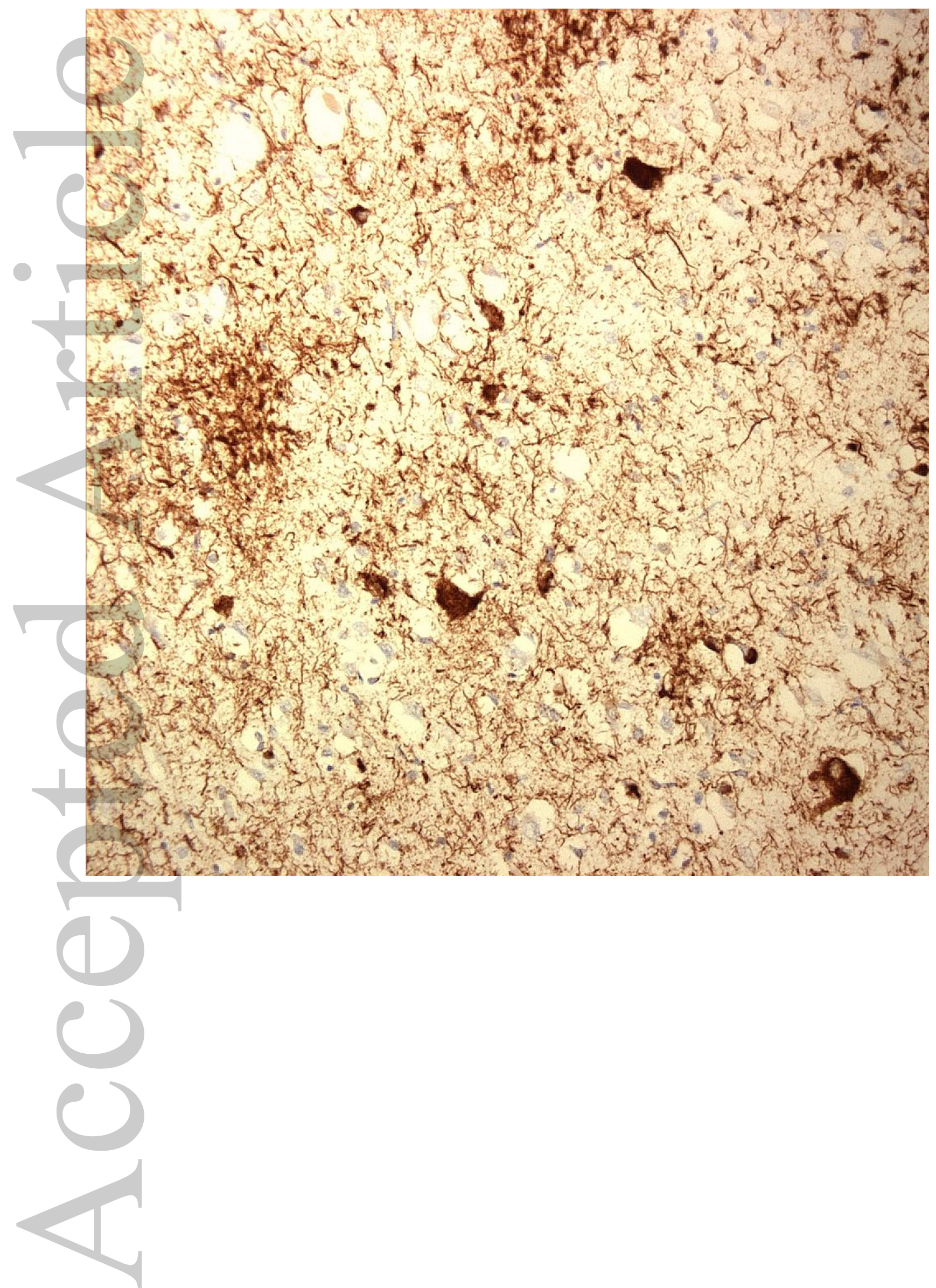

This article is protected by copyright. All rights reserved. 


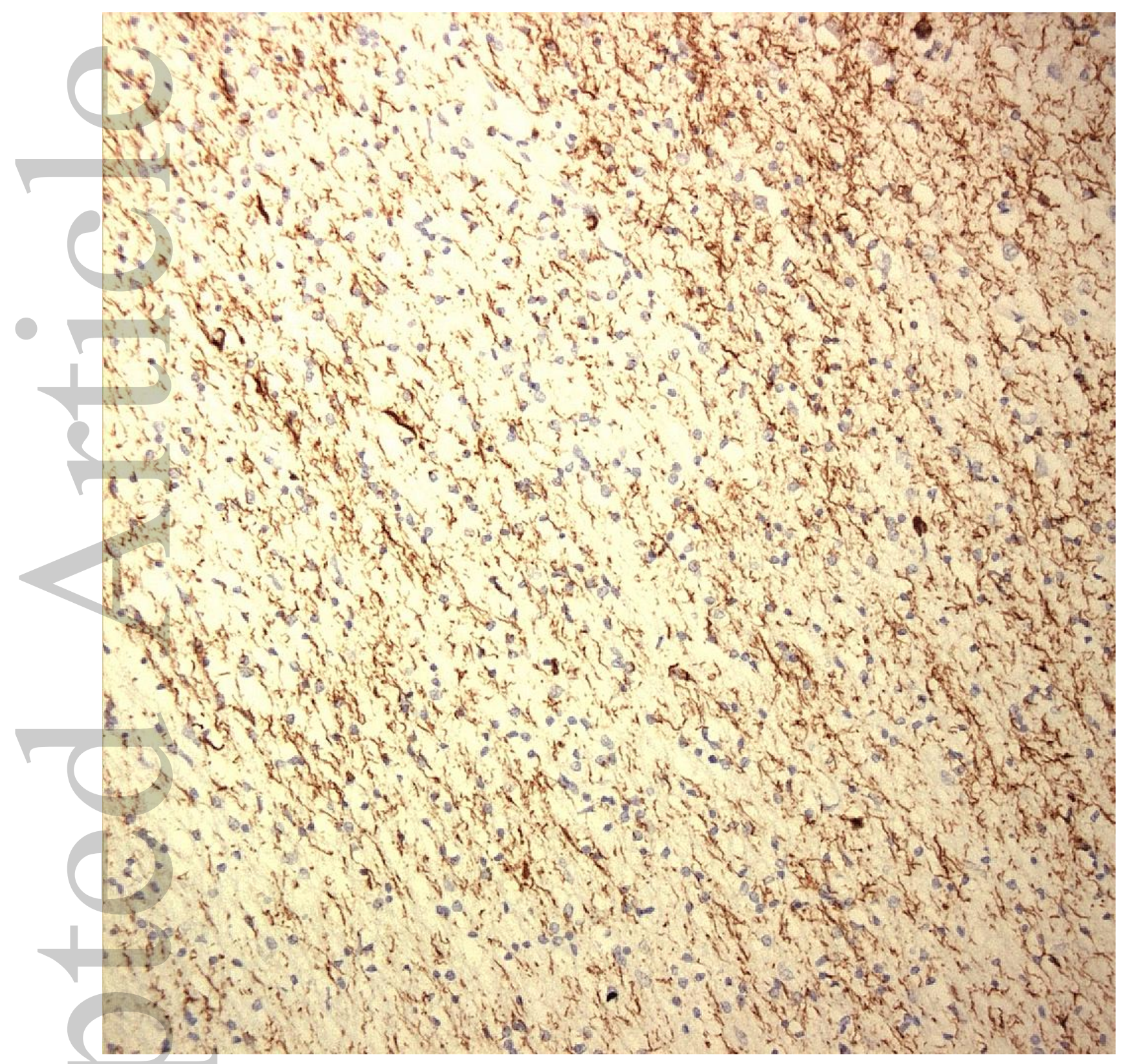

Figure 3. Microglial cells in grey (a) and white (b) matter in CBD. There appears to be more microglial cells in grey than white matter, in line with the heavy involvement of tau positive astrocytes in grey matter (as astrocytic plaques) (c) and white matter as coiled bodies (d).

CD68 immunoperoxidase (a,b), x40 microscope magnification.

AT8 (tau) immunostaining (c,d), x20 microscope magnification.

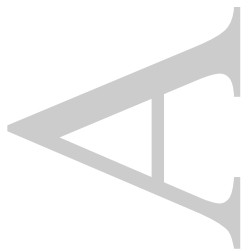

This article is protected by copyright. All rights reserved. 


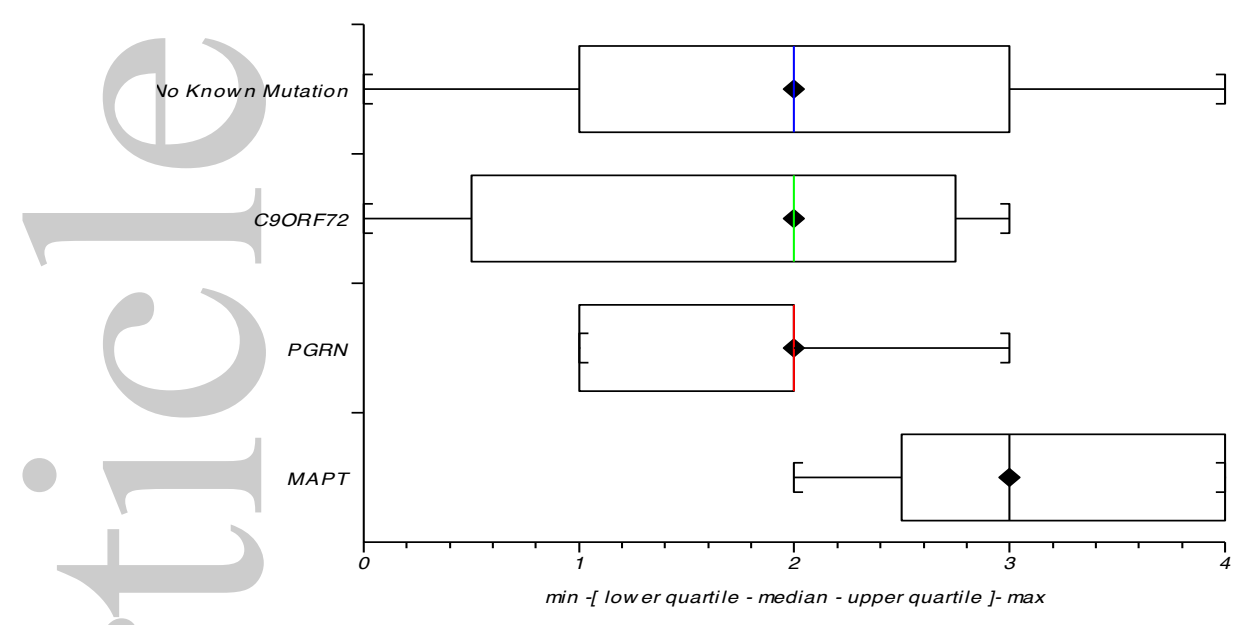

Figure 4. Extent of microglial activity in the subcortical white matter of the temporal cortex in cases with known FTLD-associated genetic mutations (MAPT, GRN, C9ORF72) compared those without known mutations.

On line Supplementary Table 1. Case details 